\section{Facile/LigFerv: Hot Water in Three Seconds, Thirty Years of Entrepreneurial Process}

\author{
Facile/LigFerv: Água Quente em Três Segundos, Trinta Anos de Processo \\ Empreendedor
}

Discipline: Entrepreneurship, Marketing

Subject: Entrepreneurial Process, Business Model

Industry: Retail, Appliances

Geography: Minas Gerais/Brazil

\section{INTRODUCTION}

Saint Joseph's Day, March 19. According to the popular belief, especially in the Northeast of Brazil, if it rains on that day, the harvest will be abundant. In the countryside of the state of Minas Gerais, it means the guava flood. The rain of the 19th drops the ripe guavas, flooding the ground with the smelling fruit. These are the "waters of March closing the summer," sang Tom Jobim. Nilson thought of the tales surrounding March 19. This day of 2020 would be remembered for other, more concrete reasons, Nilson meditated sitting in front of the computer, but without paying attention to the screen. The mayor of Belo Horizonte had decreed, for the following day, the beginning of social isolation when only essential services would be kept open. Such radical decision was aimed to contain the advance of

1. Pontifícia Universidade Católica de Minas Gerais, Programa de Pós-graduação em Administração, Belo Horizonte, MG, Brazil.

Cite as: Silva, J. P. M., Guimarães, L. de O., \& Castro, J. M. de. (2021). Facile/LigFerv: Hot water in three seconds, thirty years of entrepreneurial process. Revista de Administração Contemporânea, 25(spe), e200221. https://doi.org/10.1590/1982-7849rac2021200221.en contamination by the new coronavirus in the population, thus avoiding the overloading of hospital facilities. The whole world was going through it.

He felt lost, uncertain about the impacts of the pandemic on people, the health system, the economy, businesses. It was all very confusing yet. He thought about the product LigFerv, in the company Faciletec, in the process of business acceleration. So much effort and work in the previous year, he remembered. With a lot of investment in product certification and professionalization of the company, a new business model had been planned, along with the proposal to adopt an innovative marketing system. And now this unprecedented situation had appeared. The economic forecast signaled the worst recession since 1929.

\begin{tabular}{|c|c|c|c|c|c|c|c|c|c|}
\hline & 1 & 2 & 3 & 4 & 5 & 6 & 7 & 8 & 9 \\
\hline $1^{\text {st }}$ round & & (x) & 9 & & & & & & \\
\hline $2^{\text {nd }}$ round & & & & & & & & & \\
\hline $3^{\text {rd }}$ round & & & & & & & & & \\
\hline
\end{tabular}


Assumptions of a $5 \%$ drop in gross domestic product (GDP) were still optimistic. Immersed in this myriad of thoughts, Helena calls him back to reality: "Father, Márcio is saying good afternoon." Father and daughter had arranged a video call with Márcio, a mentor who had accompanied them on the company's acceleration project the year before, to discuss the situation.

Scared, Nilson says: "Hi, what's up?" That greeting sounded simply ridiculous.

\section{THE TRADITION OF COFFEE}

The act of drinking coffee in the morning is a tradition for most Brazilians. However, Nilson's family had a special ritual. On Sundays, the first of the five family members to get up had to make the coffee and bring a cup for those who were still sleeping. Nilson did not know if everyone shared his thoughts, but he confesses that he was too lazy to get up to brew the coffee - for him, his parents, and his two sisters.

Because of this, the family's rope alarm clock ended up having another purpose, which Nilson tells us in a simple way: "taking advantage of the clock's rope movement, a nylon rope was wrapped, pulling a wire, connecting a contact in a shower resistance that was inside a mayonnaise glass. The water boiled instantly." Finally, the water passed through a tube, obtained in the school's laboratory, and fell into a cloth filter that prepared about $500 \mathrm{ml}$ of coffee. The amount was enough to serve everyone in the house, "and it was very quiet," points out the inventor of the 'coffee-cooking clock.'

His invention, awarded at school science fairs in the early 1970s, accompanied Nilson into adulthood. While in college, while studying Electronics and Telecommunications Engineering, he made friends with Airton. His new friend, like Nilson, was given to inventions and tried to create a device to boil small amounts of water. The two came together and, sharing ideas, developed an instant water boiler.

However, because they had worked on the idea of the boiler only in the vague hours of work and studies, the project took time to be implemented. In 1982, Nilson became a university professor, starting a double life between teaching and the company that would accompany him for the next three decades. After a few attempts, the duo developed a robust model, made of molded plastic. This model was called Liga-Ferve and its operation was simple: when you turn on a knob, you have boiling water in three seconds. The limit of the reservoir could hold up to one liter of water, and the cost of electricity was minimal $-1,000$ cups of coffee per month represents an increase of R\$ 3.20 in the energy bill. Already in possession of the name, the duo of inventors began the first process of patenting the product that, for legal reasons, would have its commercial name changed to LigFerv. The innovation of the product, without similar in the market, consisted in boiling, in three seconds, the water to be used in hot drinks.

Through the network of relationships made possible by the university, Nilson and Airton found, in 1990, a partner to assist in the production of the innovative project. This partner was MC Indústrias, a medium-sized company located in the metropolitan region of Belo Horizonte. MC, which was already active in the telecommunications and industrial automation segment, took the responsibility of also venturing into household appliances. According to Nilson, "MC's philosophy was to create a kind of business incubator." Besides having at their disposal a variety of resources, such as physical space, administrative structure, machines, and equipment, the inventors of LigFerv obtained a credit line - US\$ 150,000.00 - from a development bank, which was paid off in one year of production and sales of the product. One of the interventions of the near incubator was the definition of the project's patenting process, since the patent previously requested by the inventors was incomplete.

During the partnership period with MC, market researches were carried out; there were reformulations on the design, besides the investment on tooling and production line. Between 1994 and 1995, the economic environment directly affected the parent company's investments in LigFerv production. Knowing of the need for more investments in marketing and in development of marketing channels and the financial difficulties of MC, the partnership was dissolved. Difficulties in the routine culminated in Airton leaving the project, which led to the creation of Facile in 1998, a company already independent of MC. The first factory of the company would be in Poços de Caldas, where Nilson was living at the time with his wife and daughters, attending the appointment of the university.

\section{FACILE: CREATION, SALES, AND 'SUCCESS'}

In 1999, a year after settling in Poços de Caldas, Nilson went to the United States, leaving in the city a person responsible for managing the plant and, in Belo Horizonte, his father, who coordinated the marketing of the product. The father, partner of the company, who during the 'incubation' at MC had already sold a car and bought several LigFerv to resell to the final customer, was now the only responsible for marketing the product. 
In 2000, Nilson returned to Belo Horizonte, Brazil. The remodeled product, with the design that remains today, started in 2000 and was only concluded in 2005 due to the planning meetings being carried during off hours, in general at night, in the breaks from teaching activities and with the participation of a designer, an intern, and the entrepreneur responsible for the manufacturing of the injection molds for the plastic parts of the product, who was also a professor at the university. At that moment, Nilson started to worry about the certification of the product at the National Institute of
Metrology, Quality and Technology (Inmetro). Although he considered the idea of certifying the product before putting it on sale on the market, the Brazilian legislation, at that time, did not foresee this obligation. Besides, there was the cost for the acquisition of the certification, of approximately $\mathrm{R} \$ 40.000,00$ for each test performed. But Nilson was confident of the security and durability of his product, after all, as he always repeated, "the customer buys it, likes it and he will never buy another one because it doesn't spoil."

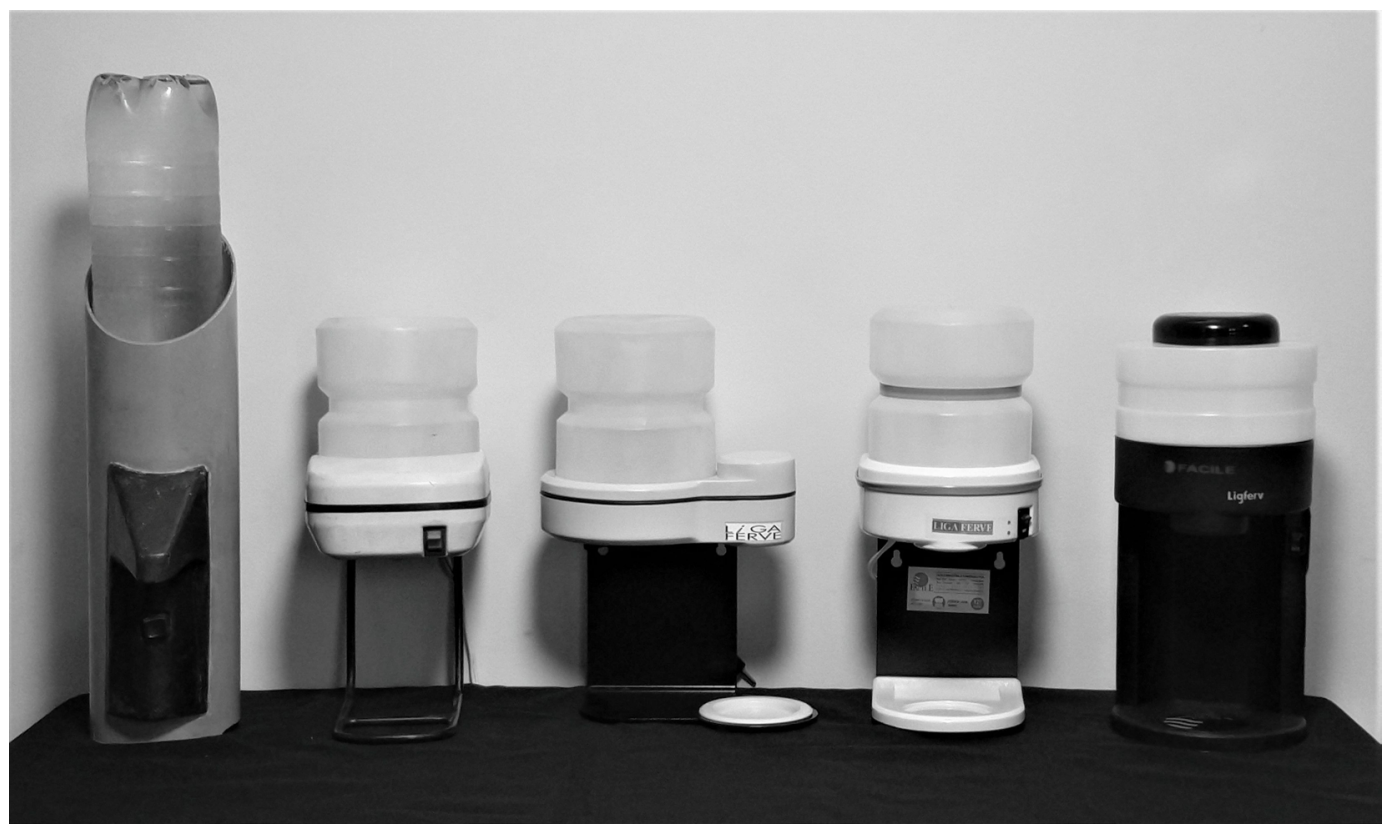

Figure 1. Evolution of the LigFerv models (1990-2006).

Source: Photo provided by the interviewed entrepreneur.

Thus, Nilson decided to postpone the certification and, in 2006, the company was ready to start professionalizing the production and marketing of LigFerv. The way of working was simple: while Nilson managed the technical issues of the product and the finances of the company, his father helped on sales, alongside a cousin on production. The recognition about the value of the product did not take long to arrive. Nilson received polls from great companies of the household appliance sector and swears that one of them copied even his slogan: "boiling water in three seconds: it saves time, saves energy and saves money." The relative success would not stop there. LigFerv was shown live in Palmirinha's culinary program, shown by TV Gazeta in São Paulo State. In one of the fairs in which he participated, he appeared in a news report on TV Globo. With good humor, Nilson comments: "The news lasts seven seconds. And in three seconds the water boils." Because of this exhibition, the next day, Nilson sold more than 1,000 machines, six times the amount sold on all the days at the fair in the previous year.

However, the positive news would stop there. Soon after, in 2012, a resolution by Inmetro would make certification mandatory for products like LigFerv. But the lack of expectation to obtain the certification did not discouraged Nilson. Even with all the difficulties, Facile has endured and commercialized more than 23,000 units of the product since 2006. The good sales retrospect, furthermore, was crucial for the selection of Nilson and Facile, in 2018, to ProTEC, the business acceleration program of the largest private university in the state of Minas Gerais. 


\section{READY TO TAKE OFF}

Nilson considers that the professionalization of Facile, even operating for so long, has happened only with the company's entry in the ProTEC acceleration program. The dispute for participation in the program was fierce and Nilson entered the dispute along 87 other companies. Among them, ideas and projects a little more established that competed for the opportunity to work for 12 months in a coworking of the mining capital and have access to financial investments and human resources, as well as mentoring from a consulting company designated by the acceleration program

Seeking to compete with other companies, mostly formed by service platform companies, he created Faciletec, the organization that would coordinate LigFerv. The partners were his two daughters and him. As Nilson points out, his thoughts were very well defined: Faciletec would enter the acceleration program to scale LigFerv production and sales. The much sought after commercial success of the product would then enable the construction of a whole family of household appliances, as innovative as the first. Among these products, there were innovative versions of a clothes dryer and a LigFerv in reverse, which would instantly chill beverages. In the end, Faciletec's performance in the program exceeded any expectations, as the company finished among the 12 finalists in the acceleration program.

In addition to the company's placement - which yielded a total of R $\$ 100,000.00$ in investments to Faciletec in exchange for $6 \%$ of the corporate share for the university -, the main gains came in the form of knowledge in management that changed completely the way Nilson saw the company itself. The mentoring showed the entrepreneur that Facile and Faciletec still operated on amateur concepts. Thus, the mentoring triggered in Faciletec significant changes, such as the creation of contracts to formalize the company's transactions and the establishment of organized processes for marketing and sales.
The advice of mentor Márcio, who followed the entire company's acceleration process by providing mentoring, covered three central issues for the future of LigFerv: (a) the need to certify the product at Inmetro; (b) obtaining a factory regularized to the standards of the International Organization for Standardization (ISO) 9001 for production certification; (c) and the possibility of finding a recurring recipe model for Faciletec, since LigFerv has a very long lifespan.

The possibility of getting recurring revenue through another business model made Nilson excited. The entrepreneur was already foreseeing a partnership with brands that sell gourmet coffee and the creation of a subscription club, through which the subscriber would receive LigFerv in his home and, monthly, the coffee for tasting. If the subscriber cancelled his agreement, the machine would be collected, since the customer would no longer have the right to use the device. For Nilson, this was a way out of the 'good problem' he had, since LigFerv has a long life span and "those who have it don't run out."

\section{YEARS OF NOVELTY}

The numbers Nilson presented to bid for ProTEC's public notice were of great help in allowing the jury approval. First, the amount of features that the product had were extensive: (a) domestic and business use for preparing hot drinks (tea, coffee, milk, among others) and instant foods (soups, ramen); (b) personal hygiene, hot water for manicure, shaving and skin cleaning activities; (c) professional area. In dentistry, it is used in dental prosthesis, to accelerate the polymerization of acrylics and the lamination of waxes and plastics for molding. In Physiotherapy, it is used to prepare hot water bags and compresses. The price of LigFerv directly on the virtual store is $\mathrm{R} \$ 197.00$ and there are options on $127 \mathrm{~V}$ and $220 \mathrm{~V}$ voltage (on the Appendix, Figure 9 shows the current design of the product). In Figure 2 you can see, in units, LigFerv sales flow between 2006 and 2018.

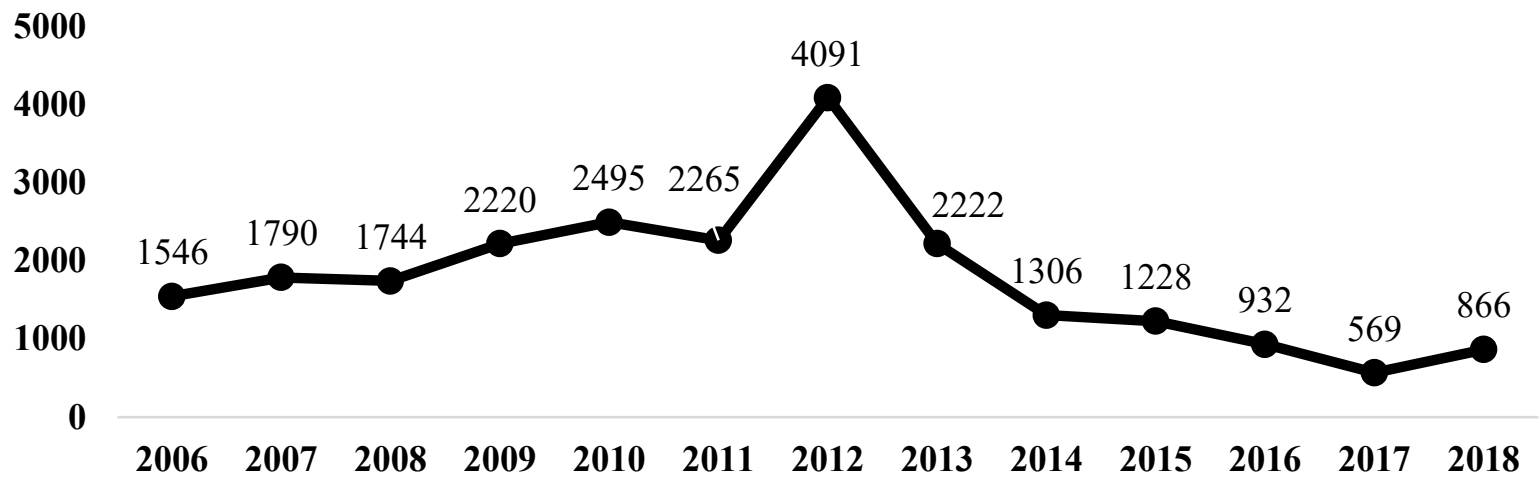

Figure 2. LigFerv sales (2006-2018).

Source: Research data. 
During the qualifying stages of the acceleration program, his daughter Helena started a survey with customers who had already purchased the product. It was identified that the vast majority of respondents use the product at work $(55.4 \%)$ or at home $(36.5 \%)$ and that most use it for the preparation of hot beverages such as teas $(66.2 \%)$, cappuccinos $(59.5 \%)$, brewed coffee (43.2\%), instant coffee $(40.5 \%)$, and is also widely used in the practice of dentistry (27\%).

Furthermore, the results surprised everyone when it was verified that the company - and the product - had no detractor clients. The great majority of its sample had known the product through indications (59.4\%) and only a small part had known through internet searchers $(8.7 \%)$.

\section{THE MARKET OF HOUSEHOLD AND PORTABLE APPLIANCES}

In the Brazilian appliance sector, as highly influenced by the social, political, and economic context, growth rates in recent years has been hit hard by the economic crisis, the strike of truck drivers, the uncertainty with the presidential elections, and, more recently, the fall in confidence (Cruz, 2018). Both in 2018 and in 2019, growth was 5\%, half of that forecasted by the sector itself $\mathrm{f}^{1}$. It should be noted, however, that the negative scenario ended up elevating the repressed demand, leaving a growth potential to be explored in the coming years.

Portable appliances, with lower values when compared to household appliances, show a mild but consistent evolution ${ }^{1}$. However, the current situation is not comfortable and recovery tends to be slow. In April, retail sales fell $16.8 \%$, the worst result since the beginning of the historical series. However, social isolation and staying at home, met by the Brazilian population, also prevented a further decline through online retail sales. In the first quarter of 2020, the physical retail registered retraction in a wide range of electronics, but was sustained by the growth of its online counterpart. Coffee makers, for example, grew $86.1 \%$ in the period with sales through virtual channels.

Figure 3 shows the variations in performance of the household appliance sector in Brazil in the year 2020.

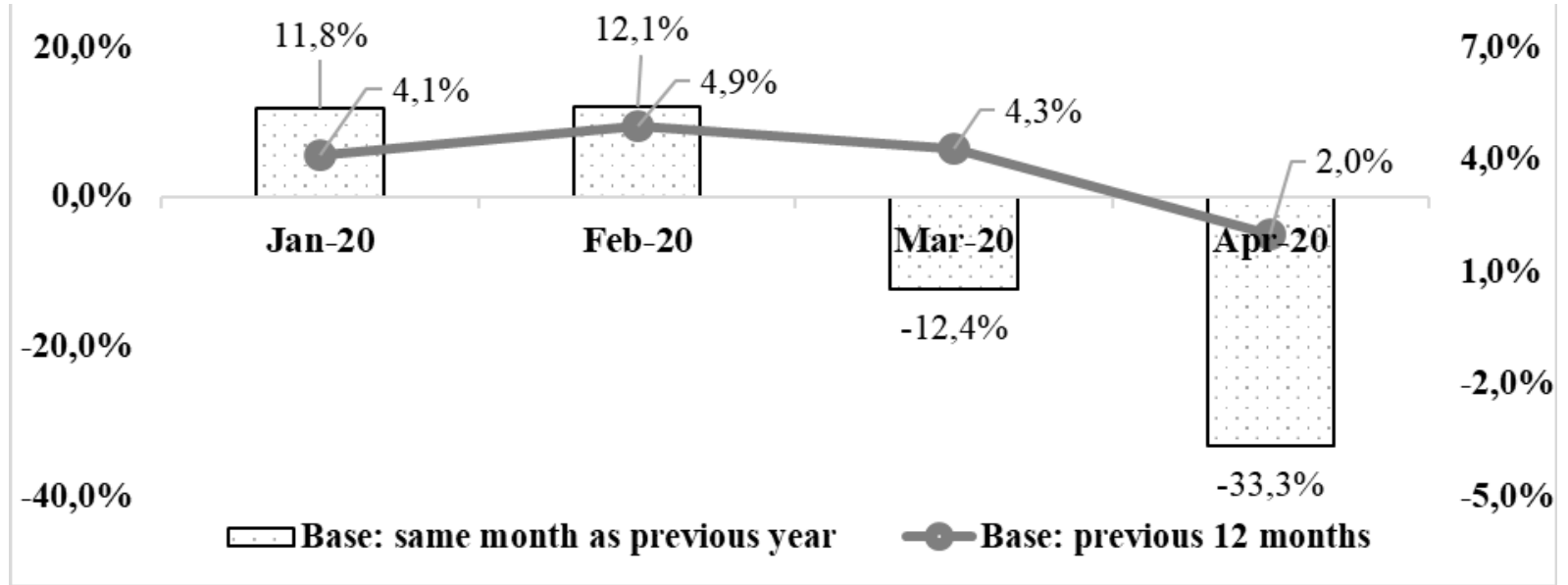

Figure 3. Sales volume of household appliances in the retail trade — monthly comparison (\%).

Source: Agência IBGE Notícias (2020). Vendas no varejo variam -0,1\% em dezembro e acumulam alta de 1,8\% em 2019. Retrieved from https:// agenciadenoticias.ibge.gov.br/agencia-sala-de-imprensa/2013-agencia-de-noticias/releases/26856-vendas-no-varejo-variam-0-1-em-dezembro-e-acumulam-alta-de-1-8-em-2019

\section{THE HOT BEVERAGE MARKET}

Hot drinks are among the most consumed types of beverages in Brazil and in the world. Tea holds the first position, with approximately 400 billion liters consumed per year. Coffee is in 5th place, with approximately 200 billion liters consumed ${ }^{2}$, and the expectation was for record consumption of the beverage in the year 2020, of approximately 166 million bags worldwide. In Brazil, coffee consumption is predominant: per capita consumption has shown continuous growth over the last two decades and reaches $6.02 \mathrm{~kg} /$ year, moving over $\mathrm{R} \$ 8.5$ billion. This data positions the country as one of the largest coffee producers and consumers in the world. Coffee powder is still the most consumed, accounting for approximately $80 \%$ of the volume sold. Roasted beans and capsules are also representative, and it is expected that in 2021 they will reach the mark of $19 \%$ and $1.1 \%$ of sales volume in the domestic market, 
respectively. Premium coffee consumption already accounts for about $10 \%$ of the market ${ }^{2}$.

Figure 4 shows the evolution of per capita consumption in Brazil between 1996 and 2016.
Tea, on the other hand, has less adhesion in the national territory and the country is not among the 15 biggest consumers of the beverage. On the other hand, the versatility of the tea is a differential, since the drink can be used for hydration, refreshment, indulgence, or functional energy source ${ }^{3}$.

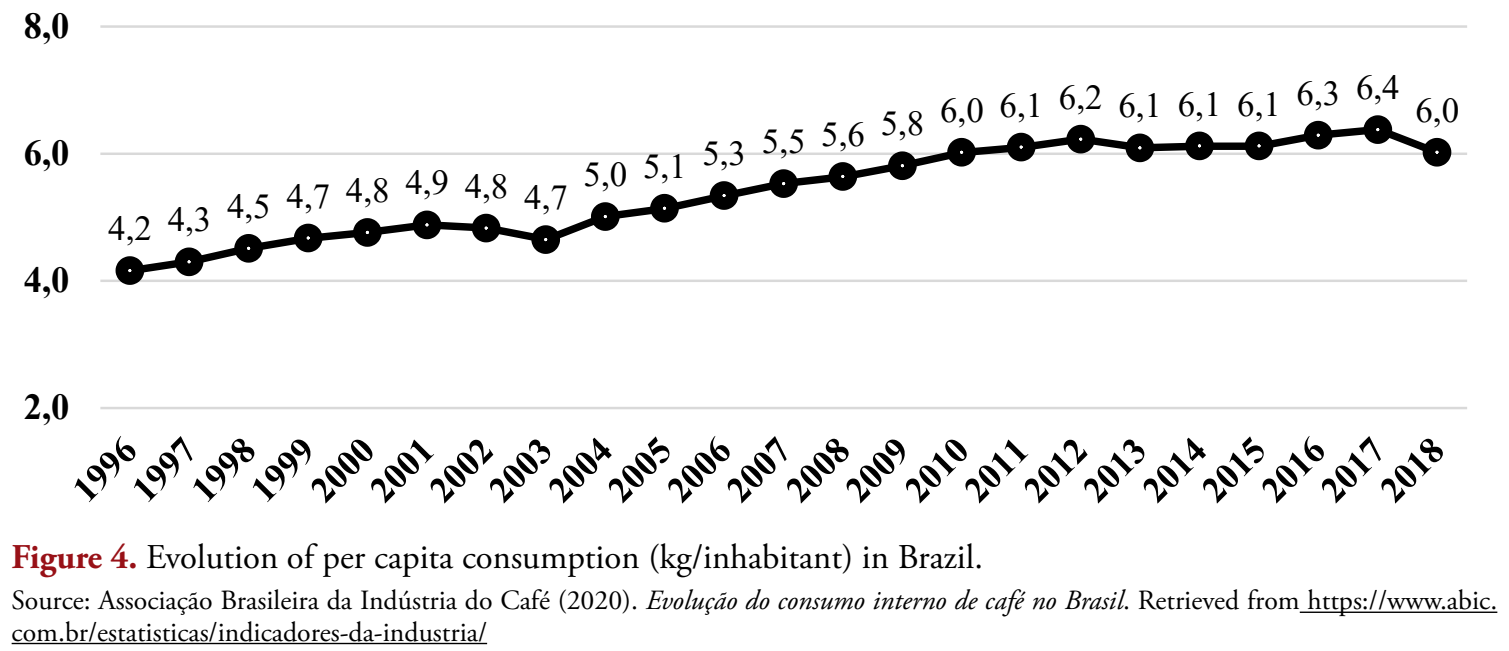

\section{PANDEMIC AND CONSUMPTION CHANGES}

The COVID-19 pandemic has transformed the routine of many companies and citizens around the world. In Brazil, the first quarter of 2020 brought a GDP decrease of $1.5 \%$, according to Figure 5.

This drop has answered for the decrease of $60 \%$, on average, of the $89 \%$ invoice of small companies of the country. In spite of this, the difficulties linked to the pandemic demanded a digital turnaround, once approximately $30 \%$ of the small companies have adhered to measures such as online sales through social networks. More specifically, $11.7 \%$ began managing their bank accounts through financial institutions' applications and another $7.5 \%$ began selling through mobile applications ${ }^{4}$.

A projection of behavior change was also identified on consumers. With the expectation of income reduction, the expenses of the Brazilians turned to the consumption of items for the home. In April, among 32 categories including products and services of different natures - the only ones expected to increase consumption by Brazilian families were grocery products and cleaning materials 5 . The act of online buying also uncovered new horizons for organizations. In retail, the situation of some companies is of expressive increase in the number of sales, due to the operations made online, but with losses in the profit margins, consequence of the maintenance of their physical structures.

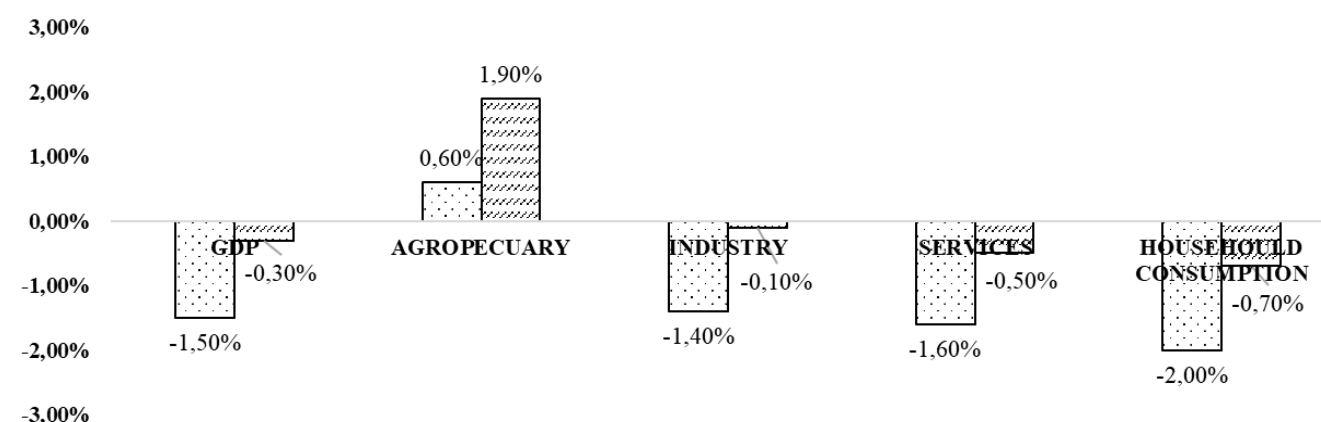

$\square$ Immediately preceding quarter / quarter (with seasonal adjustment)

$\square$ Quarter / same quarter as last year (no seasonal adjustment)

Figure 5. Economic indicators (GDP) - 1st quarter of 2020.

Source: Agência IBGE Notícias (2020). PIB cai 1,5\% no $1^{\circ}$ trimestre de 2020. Retrieved from https://agenciadenoticias.ibge. gov.br/ agencia-sala-de-imprensa/2013-agencia-de-noticias/releases/27837-pib-cai-1-5-no-1-trimestre-de-2020 


\section{AND HALFWAY THERE WAS A VIRUS}

As soon as he greeted mentor Márcio on the video call, the connection dropped. As Helena reestablished the connection, Nilson still thought, as she scribbled on the 2012 paper agenda that was on the table: the year 2020 had begun promising for him and Faciletec. With the $\mathrm{R} \$ 100,000.00$ won at ProTEC, the entrepreneur put aside 18 water boilers (LigFerv) that had already passed a pre-test, to send them to Rio Grande do Sul, where they would perform the final tests for certification. Meanwhile, one of the friends who helped him prepare the current LigFerv model was already adapting his factory's processes to obtain ISO 9001 to produce the certified boiler. In addition, he had also started to prospect some stylized aluminum cans to package the coffee to be delivered monthly to future LigFerv subscribers in a commodatum system. The proposal provided for a subscription-marketing model throughout the country. To enrich the consumer experience in coffee tasting, each month the business model assumed the sending of a type of gourmet coffee, varying by region of Brazil.

He was thinking about this when Márcio returned to video calling. Would the subscription-based business model be feasible for the post-pandemic product? Would the previous year's planned acceleration process still make sense in the 'new normal'? Or should the manufacture and sale of the device in the traditional format still prevail? Would it be strategic to combine a hybrid model, traditional sales and signature? At that moment, his feeling was that he was always starting over, always in the early stage of his entrepreneurial process.

\section{NOTES}

1. Mercado e Consumo (2020, January). Setor de eletroeletrônicos cresce 5\% em 2019. Retrieved from https://www.mercadoeconsumo.com.br/2020/01/29/ setor-de-eletroeletronicos-cresce-5-em-2019/

2. Euromonitor Research (2017, December). Ranked: Top 15 tea-drinking countries. Retrieved from https://blog. euromonitor.com/ranked-top-15-tea-drinking-countries/

3. Euromonitor International (2019). Tea in Brazil. Retrieved from https://www.euromonitor.com/tea-in-brazil/report

4. Serviço Brasileiro de Apoio às Micro e Pequenas Empresas (2020, May). O impacto da pandemia de coronavírus nos pequenos negócios. Retrieved from https://m.sebrae.com. br/sites/PortalSebrae/artigos/o-impacto-da-pandemia-decoronavirus-nos-pequenos-negocios, 192da538c1be1710V gnVCM1000004c00210aRCRD

5. Charm, T., Grimmelt, A., Kim, H., Robinson, K., Lu, N., Mayank, Ortega, M., Staack, Y., \& Yamakawa, N. (2020, October). Consumer sentiment and behavior continue to reflect the uncertainty of the COVID-19 crisis. McKinsey \& Company. Retrieved from https://www.mckinsey.com/ business-functions/marketing-and-sales/our-insights/aglobal-view-of-how-consumer-behavior-is-changing-amidcovid-19 


\section{Teaching Notes}

\section{ABSTRACT}

This teaching case aims to discuss an entrepreneurial process involving the trajectory of an innovative product over thirty years until culminating in a significant event in the change of the company's business model in the midst of the crisis triggered by the pandemic of the new coronavirus. The case offers opportunities for discussing theories related to the entrepreneurial process - causation and effectuation logic. In addition, in the course of the recent trajectory, in which the company is selected for an acceleration program, a possible change in the business model emerges. Reported from the perspective of the founder, but also supported by materials from secondary sources, the case presents the trajectory of Facile. The teaching strategy consists in enabling the student to learn, first, about the entrepreneur's decision-making and action, emulating transitions between the causation and effectuation logic throughout the case to explain such behavior. Subsequently, the case inquires about possible alternatives for changing the business model for the company after the acceleration program, in which students will be able to identify more suitable alternatives in the face of both the company's skills and, not least, the pandemic that changed the behavior of customers and entrepreneurs.

Keywords: entrepreneurial process; effectuation; business model; pandemic.

\section{RESUMO}

Este caso de ensino objetiva discutir um processo empreendedor envolvendo a trajetória de um produto inovador ao longo de trinta anos até culminar em um significativo evento de mudança do modelo de negócio da empresa em meio à crise desencadeada pela pandemia do novo coronavírus. $\mathrm{O}$ caso oferece oportunidades para a discussão de teorias relacionadas ao processo empreendedor - lógicas causation e effectuation. Além disso, no curso da trajetória recente, em que a empresa é selecionada para um programa de aceleração, emerge uma possível mudança do modelo de negócio. Relatado a partir da ótica do fundador, mas também apoiado em materiais de fontes secundárias, o caso apresenta a trajetória da empresa Facile. A estratégia de ensino consiste em possibilitar ao aluno aprender, em primeiro lugar, sobre a tomada de decisáo e açáo do empreendedor emulando ao longo do caso transiçóes entre as lógicas causation e effectuation para explicar tal comportamento. Posteriormente, o caso indaga sobre possíveis alternativas de mudança do modelo de negócio para a empresa após o programa de aceleração, quando os alunos poderão identificar alternativas mais adequadas, em face tanto das competências da empresa quanto, não menos importante, da pandemia que alterou o comportamento dos clientes e dos empreendedores.

Palavras-chave: processo empreendedor; effectuation; modelo de negócio; pandemia.

\section{LEARNING OBJECTIVES}

This case was developed for use in teaching situations in lato sensu undergraduate and graduate courses in the disciplines Entrepreneurship and Innovation, Strategy, Business Models, Marketing, and other whose objectives are focused on the process of creating and developing innovative businesses. It can also be used in free entrepreneurial training courses, such as those offered by Sebrae, incubators, and business accelerators.

The expectation is that students can develop skills to evaluate markets and business models, improving their skills in scenario analysis and marketing strategies.

The didactic objectives, therefore, are: (a) to understand the entrepreneurial process from different analysis logics: effectuation and causation; (b) to analyze how the entrepreneurial process can be strengthened by incubation or business acceleration mechanisms; (c) to analyze how participation in an acceleration process can generate review in the business model; (d) to analyze how acute crises and unforeseen events can affect the implementation of business models planned in the acceleration process.

Based on the objectives exposed, the following questions were elaborated:

Initial activity: Elaborate a mental map and a timeline as a synthesis of the events of the case. What were or are the main challenges during the entrepreneurial trajectory?

1. Analyze the entrepreneurial process described in the case through the causation and effectuation logics.

2. Imagine yourself in the place of Márcio, the mentor of Nilson. What advice would you give Nilson about the future of Faciletec?

3. Which business model should Faciletec follow when selling its LigFerv product? 


\section{THE PROTAGONIST AND SOURCES OF INFORMATION}

The case is presented from the entrepreneurial history of engineer Nilson de Figueiredo Filho, from his experience in a process of acceleration, surprised in this trajectory by a serious public health problem - the COVID-19. The crisis, of gigantic proportions, implied social isolation, business suspension, cooling of commercial transactions, unemployment, and, in the specific case, paralysis of the process of certification of the product, of the factory, and of readequation of the business model.

The data for the elaboration of the case were obtained through videos, pitches, media reports, market research reports, company portal, media reports provided by the protagonist, not only from historical aspects of the company, but also from the documentation related to the acceleration process lived in the year 2019. In addition to the documentary data, interviews were conducted with the founding partner and the owner partner, the daughter of the protagonist.

\section{DIDACTIC-PEDAGOGICAL ORIENTATION FOR CASE DISCUSSION}

In order to make the discussion of the case more fruitful, it is recommended that the teacher carries out previous theoretical discussion about the entrepreneurial process causation and effectuation logics - and, if the teacher is interested in the realization of Question 3- which figures as an extra task - also exercise the theme of business models. The following readings are indicated: Sarasvathy (2001), Sarasvathy and Dew (2005), DaSilva and Trkman (2014) and Osterwalder and Pigneur (2010).

After the presentation and discussion of the theoretical fundamentals, the idea is for the teacher to organize the class in three groups and allocate at least 20 minutes for reading in case the students have not previously done the reading and 25 minutes for the discussion of the case questions to the groups.

After the discussion in small groups, the teacher organizes the plenary session, allocating 60 minutes for the consolidation of the answers thought for the challenges of the case. The closing of the plenary discussion should be done in the remaining 15 minutes.

\section{Opening of the discussion}

Initial activities: Building the case overview (25 minutes). As a warm-up for discussion of the case, two activities are suggested that will precede the questions concerning the case:
A) For a general understanding of the case, it is recommended that students elaborate a mental map and a timeline, where the events of the case can be synthesized. Initially, for the mind map, it is suggested that participants answer questions such as: What are the main characters of the case presented? What is the main problem? What were/are their main challenges during the entrepreneurial trajectory? Then, using the timeline, it is suggested that the students punctuate the events they consider critical, marking them until the end of the case. Looking for the contextualization of the timeline, some questions can be used, such as: Taking into account the entrepreneurial process exposed, what has changed over time? Is it possible to perceive some period of transition? If so, what has changed from one period to another? How do you imagine the decision-making process was carried out in the different periods?

B) Afterwards, it is recommended that the teacher organize the information, in a slide (example: Figure 10, in the Appendix), about the product/service subscription market compared to the traditional product/service sales market, specifically about the consumption of hot beverages. The objective is for students to view information relevant to the analysis of the case.

Question 1 - Analysis of the entrepreneurial process: causation and effectuation logics (60 minutes)

The traditional models that propose to plan and explain the entrepreneurial process are based on planned sequential phases (Hisrich, Peters, \& Shepherd, 2014). These stages usually consist of identifying and evaluating the opportunity, company development, growth, and management, aiming at predicting results and in a stable and perfect market perspective (Bourry \& Teixeira, 2019). These models consider that the business, to be successful, must develop a planning, such as a business plan.

Feger, Vieira and Chemim (2016) presented a model with the stages and activities of the process of creating an enterprise (Table 1).

Sarasvathy (2001) proposed a new perspective effectuation - foranalysisofentrepreneurship. In herevaluation, the traditional models of evaluation of the entrepreneurial process are not adequate to the initial phase of the business. In general lines, the analysis of the process of creation of a company from the effectuation logic starts from the principle that, in its decision-making process, the entrepreneur considers three categories that correspond to a set of means: (a) who they are - it concerns their own characteristics, preferences, and abilities; (b) what they know - it is the knowledge and information they possess; (c) who they know - that is, the social networks they are part of (Sarasvathy, 2001). 
Table 1. Stages and activities in the creation of an enterprise.

\begin{tabular}{|c|c|c|c|c|}
\hline Internship & Initiation & Preparation & Launch & Consolidation \\
\hline \multirow{7}{*}{ Activities } & \multirow{7}{*}{$\begin{array}{l}\text { Identifying the business } \\
\text { opportunity } \\
\text { Reflection and development of } \\
\text { the business idea } \\
\text { Decision to create the enterprise }\end{array}$} & Business plan elaboration & Legal procedures & \\
\hline & & Conclusion of marketing & \multirow{3}{*}{$\begin{array}{l}\text { Full dedication to the enterprise } \\
\text { Organization of facili-ties and } \\
\text { equipment }\end{array}$} & Promotion and marketing \\
\hline & & research & & $\begin{array}{l}\text { activities } \\
\text { Sales }\end{array}$ \\
\hline & & \multirow{2}{*}{$\begin{array}{l}\text { Creation of the business team } \\
\text { (partners) }\end{array}$} & & Dales \\
\hline & & & \multirow{3}{*}{$\begin{array}{l}\text { Development of the first service } \\
\text { products } \\
\text { Hiring employees } \\
\text { First sales }\end{array}$} & Reach of balance point \\
\hline & & Registration of trademark or & & Management \\
\hline & & patent & & \\
\hline
\end{tabular}

Note. Source: Feger, Vieira and Chemin (2016, p. 1043).

Table 2. Decision-making in causation and effectuation processes.

\section{Causation}

Effectuation

A certain objective to be achieved or a decision to be made (usually well- Certain set of means (usually consisting of relatively unchanged structured and specific).

characteristics/circumstances of the deci-sion-maker).

A set of alternative means or causes (which can be generated from the A set of effects or possible operationalizations of gen-eralized aspirations decision process). (generated mainly by the decision process).

Restrictions on possible means (usually imposed by the environment).

Restrictions and opportunities for possible effects (usually imposed by limited means, as well as the envi-ronment and its contingencies).

Selection criteria among the means (usually maxi-mization of expected Criteria for selecting among the effects (usually a pre-determined level of return). accessible loss or acceptable risk related to the given means).

Note. Source: Ferreira (2020, p. 42).

For Sarasvathy (2003), “... the effective entrepreneur starts with who he is, what he knows and who he knows, to find at least one client or partner who is interested in a product or service he can offer" (Sarasvathy, 2003, p. 214). The author suggests the following questions: "Given what I am, what I know and who I know, what can I do? What kind of effects can I create?" (Sarasvathy \& Dew, 2005, p. 543).

In short, the analysis of the entrepreneurial process from the traditional logic — or causation - considers an expected result for the entrepreneurial action. The entrepreneur, in this case, selects the available means to obtain such result. In the analysis of the entrepreneurial process from the effectuation logic, it is understood that the entrepreneur holds a set of means and, thus, will evaluate the possible effects that can be created with this set of means (Sarasvathy, 2001).

In other words, the effectuation logic does not consist of a process of choosing between given alternatives, but of creating one's own alternatives and, together, discovering and evaluating desirable and undesirable qualities of various possible outcomes. This means, in the effectuation model, that the entrepreneur, in his decisions, considers four principles: (a) the losses that can be accepted; (b) the necessary alliances so that uncertainties can be reduced; (c) the reflection on how to better exploit contingencies; and (d) how to manage a future that, by its nature, is unpredictable (Sarasvathy, 2001; Sarasvathy, Forster, \& Ramesh, 2020).

Table 3. Principles of effectuation theory.

\begin{tabular}{|c|c|}
\hline Principles & Features \\
\hline Acceptable loss costs & $\begin{array}{l}\text { It consists in testing all possible strategies considering the limited means that have been given from the predetermination of how } \\
\text { much loss is acceptable. "The effectuator prefers choices that create more options in the future over those that maximize returns } \\
\text { in the present" (Sarasvathy, 2001, p. 252). }\end{array}$ \\
\hline Strategic alliances & $\begin{array}{l}\text { Focus on forming strategic alliances with stakeholders in order to reduce and/or eliminate uncertainty. "Stakeholder pre- } \\
\text { commitments make uncertainty irrelevant by 'delivering' a future that looks very similar to what was contracted" (Sarasvathy, } \\
2003 \text {, p. 210). }\end{array}$ \\
\hline $\begin{array}{l}\text { Contingency } \\
\text { Exploitation }\end{array}$ & Contingencies that arise unexpectedly over time are best explored by the effectuation process. \\
\hline $\begin{array}{l}\text { Controlling an } \\
\text { unpredictable future }\end{array}$ & $\begin{array}{l}\text { Focuses on conflict issues of an unpredictable future. "To the extent that we can control the future, we do not need to predict it" } \\
\text { (Sarasvathy, 2001, p. 252). }\end{array}$ \\
\hline
\end{tabular}

Note. Source: Adapted by Ferreira (2020) from Sarasvathy (2001, p. 252). 
Considering the theory presented above, it is proposed:

a) Identify and analyze the moments of the entrepreneurial trajectory characterized by traditional elements - planning, evaluation, research — based on the decisions of the entrepreneur and those identified as being based on the effectuation logic.

b) Analyze the principles - acceptable loss costs, strategic alliances, contingency exploration, and control of the unpredictable future - used by the entrepreneur in the creation and trajectory of Facile. In relation to Question 1A and considering the information presented in the case, some events that occurred during Nilson's entrepreneurial trajectory stand out and can be understood as actions taken from the effectuation logic and others through planning (causation). Under the effectuation logic, it is possible to cite, for example, the construction of the coffee strainer clock, which can be understood as the first prototype of the product that would be launched in the market in the following years. From the dissatisfaction in waking up early (who am I), the invention, created with materials obtained from the school where Nilson studied (what do I know? what can I do?), had the support of the institution by submitting it and awarding it in the scientific event in which the student participated (interaction with stakeholders). For the first time, the educational institution to which Nilson was linked would help him develop his ideas (stakeholder commitment to effectuation).

The young man's interest in Engineering would put him back in touch with the networks, but now at the university. It was within the university campus that Nilson nurtured his first co-worker, where they joined the two ideas to create the first instant water boiler. His relationships in the Engineering Department, already as a professor at the university, would give him access to an infrastructure where he could manufacture his product, when he started the partnership with MC Indústrias in 1990. The company, which acted almost as a business incubator, provided valuable resources to Nilson, including in the process of patenting his invention. Still in the meantime, aspects of the economic conjuncture led to the closing of the partnership. Due to this contingency, Facile was founded, allowing the continuation of Nilson's entrepreneurial process.

Subsequently, a series of trials and errors - and hits — shaped Facile's business model. Through relationships with family and friends, the company was able to structure and maintain itself. A close friend, in addition, was the person who alerted him of his future problem with the obligation of certification at Inmetro. The products that were traded on 2006-2012 period were result of familiar operation, both in production and in word-of-mouth sales, besides the sales at fairs.
In the case of decisions under the logic of causation, one can identify them at the moments when the entrepreneur got involved with partners who would prove to be development agents for the business and the company. Initially, when still in partnership with MC Indústrias, the entrepreneur would have access to several resources to strengthen the business, including market research and reformulations on product design to make it more competitive. Management processes based on practices already established by theoretical bodies and already experienced by other companies can be considered as of causation logic. Similarly, the company's entry into the acceleration process can also be recognized as causation in nature. The entrepreneur himself considers that the professionalization of the company occurred from ProTEC, when it replaced amateur management practices. Organized processes were built for negotiation with customers and suppliers, as well as marketing and sales processes. In addition, the planning and preparation for the conquest of Inmetro certification were paralyzed due to a contingency, the beginning of the pandemic.

Regarding Question 1B, in which the four principles of the effectuation logic process will be analyzed, the following directions are proposed:

a) Acceptable loss costs: Nilson's decision to undertake while in fixed employment suggests that the entrepreneur balances stability with risk. Instead of becoming an opposition to his desire to undertake, the university ends up acting in a way that helps the development of his ideas, mainly through the network of relationships and knowledge acquired there. Moreover, the entrepreneur seems willing to invest cautiously in his business, as in the option for not making the certification of Inmetro when it was not compulsory.

b) Strategic alliances: alliances with partners permeate Nilson's entire trajectory as an entrepreneur, from the conception of the company in partnership with another inventor, the partnership with MC Indústrias and product development, the sales made at fairs and events, and the subsequent participation of the company in the acceleration process. More recently, the manufacturing of the product in the industrial plant of a friend. The pre-testing of his product in the university laboratories demonstrates how alliances can be important for the development of the entrepreneur's new ideas.

c) Contingency exploration: the most recent contingency exploration that the entrepreneur aims at is the expressive and perennial increase in the consumption of hot beverages in the national context - mainly the consumption of coffee in the traditional and gourmet format — and the greater sale of electronics. However, other moments have shown that the contingencies include moments of transition in the company, such as the change in the political-economic scenario of the early 1990s and the end of the partnership 
with MC Indústrias. Besides, Nilson's decision on enrolling the company on the acceleration program realized by the university represents an example of contingencies exploration.

d) Controlling an unpredictable future: the pandemic generates an unpredictable future as it subverts customer behavior regarding their buying habits. However, the opportunity to exploit a constantly growing hot beverage market seems to be an attempt to minimize possible risks. In addition, the bet on the market blinds eventual changes in the behavior of future customers, such as the possibility of boycotting unsustainable electronic products or those that have the recycling process with high complexity.

After the analysis of the entrepreneurial process that permeates Nilson's trajectory, the following activity puts the eyes on the present, that is, on the dilemmas faced by the entrepreneur during the acceleration process and on the pandemic itself, which has greatly affected current decisions.

Question 2-Imagine yourself in the place of Márcio, Nilson's mentor during the entire acceleration program. What advice would you give Nilson about the future of Faciletec? (35 minutes)

At this moment, it is proposed that the participants imagine themselves in the place of Márcio, Nilson's mentor, during his trajectory at ProTEC. The current situation is in place: Nilson has already separated the equipment for product certification and testing with the subscription service is about to take place. With the data collected in the body of the case, it is suggested that students make general recommendations that can help Nilson after the end of the pandemic state.

The questions are aimed at introducing participants to the position of counselor and mentor. From the data presented, it is desirable that participants use them to support their arguments. It is interesting that the teacher amplifies the discussion with distinct answers, but that they remain based on the data previously collected.

To generate the recommendations, the following questions are suggested: What changes with the new scenario of COVID-19? Should the company change its plans, delay them, or cancel them? That is, should the tests be maintained, as well as the sale through the subscriptions? What would you do if you were the entrepreneur responsible for the company in this moment of uncertainty? After the pandemic, should Facile review its aspirations (what would you like to become)? Are there any creative alternatives for the company to use at this time?

In a context of difficulties generated by the pandemic and, considering the characteristics of the product and the current business model, the acceleration process leads to a possibility of profound change in the Faciletec business model. This is the critical question to be answered in the following activity.

Question 3 - Which business model should be followed by Faciletec when selling its LigFerv product? (85 minutes)

This question was proposed as an additional discussion to the two previous questions, being at the teacher's discretion - depending on the availability and maturity of previous discussions - its realization. As mentioned in the guidelines below, the task unites the perspective of the entrepreneurial process undergone by Nilson with approaches that deal with business models and strategy.

LigFerv started the year 2020 involved in several plans, many of them stemming from participation in the acceleration program. The starting point was the conception of a new business model based on monthly subscription boiler in lending and monthly delivery of gourmet coffee.

Despite the various existing definitions and models, there is a consensus that the business models are used to represent how enterprises perform their operations dynamically (Andreini \& Bettinelli, 2017; Osterwalder \& Pigneur, 2003), combining existing resources to generate value for the client and also for the organization (DaSilva \& Trkman, 2014). One of the models for building business models is the Business Model Canvas (Osterwalder \& Pigneur, 2010), suitable for studies in disciplines of a practical nature (Andreini \& Bettinelli, 2017). The framework - canvas - that delimits the development of the business model is subdivided into nine blocks: (a) market segments; (b) value proposal; (c) channels; (d) customer relations; (e) sources of revenue; (f) key resources; (g) key activities; (h) key partners; and, finally, (i) cost structure.

It is then suggested a subdivision of students into three distinct groups - adaptable according to the number of students in the classroom - for reflection and definition of a business model based on the canvas model. It is recommended to start the activity with the discussion about which will be the value proposal(s) that will guide the development of the business model for Faciletec/LigFerv. Later, for each group, part of the model may be indicated: (a) market segments, customer relationship, and channels; (b) main resources, key activities, and key partners; (c) cost structure and revenue sources.

It is noteworthy that, since companies seek the use of information and communication technologies for business development, it is common that new and complex value propositions arise, along with a large number of possible distribution channels. The increase in complexity of the model is reflected in the value generated by the business model, and is also a function of the performance of external stakeholders, such as suppliers and partners who operate in distribution (Osterwalder \& Pigneur, 2003). 
However, the opportunity to develop a business model brings with it important questions that can be deepened by the instructor. Therefore, even before the model is built, one way to enrich the creation of the model by the students and foster debate is to discuss the difference between two concepts that are usually taken as synonyms: business model and strategy (DaSilva \& Trkman, 2014; Teece, 2017). The difference between the two is part of a time premise. While strategy reflects what a company would like to be, the business model describes what the organization definitely is in that period (DaSilva \& Trkman, 2014; Teece, 2017). To this end, it is proposed that the group of students begin the task of building the framework after answering questions such as: "what will Faciletec's strategy(s) be?"; "what would Faciletec like to become?"; "what are the capabilities of the organization, that is, what resources does it have to build, test, and review the business model we will plan?”

An example is the signature economy, which has existed for some time but has expanded with the advance of digital forms of consumption (Citi, 2020). In this environment of exchanges, one comes across actors who have popularized the term - and the business — such as video and music streaming companies, as well as those of digital games, but there are also small businesses that seek to make good use of the advantages of the subscription economy. Among them are more predictability in revenue projections, direct contact with the client, and economies of scale, given the relatively low fixed costs (Zuora, 2019).

In Brazil, one of the subscription models that gained popularity in the years 2010 were the subscription clubs, a market that already has over 800 companies, with revenues of about R \$ 1 billion in 2018 (Simóes, 2019). These clubs are, most of the time, distributed in two ways. One of them acts in the delivery of recurring products, which today account for a wide range of products, from pet food to razor blades. The other works in the delivery of products through the curatorship of specialists, such as wines and books (Associação Brasileira de Comércio Eletrônico, 2017).

From the restrictive measures of circulation due to the COVID-19 pandemic, small businesses, when embarking on digital sales mechanisms, also began to flirt with the signature economy (Barbo, 2020). These are companies that try to take advantage of the trend of facilitated and recurring payments, such as distance credit card purchases, which reached the amount of $\mathrm{R} \$ 86.7$ billion in the first quarter of 2020, an increase of $23.2 \%$ compared to 2019 (Albuquerque, 2020).

The following is a proposal for an initial framework with the business model structured by Faciletec until the moment it enters the acceleration program. The questions suggest possible opportunities that were discussed during the mentoring and were not yet being explored.

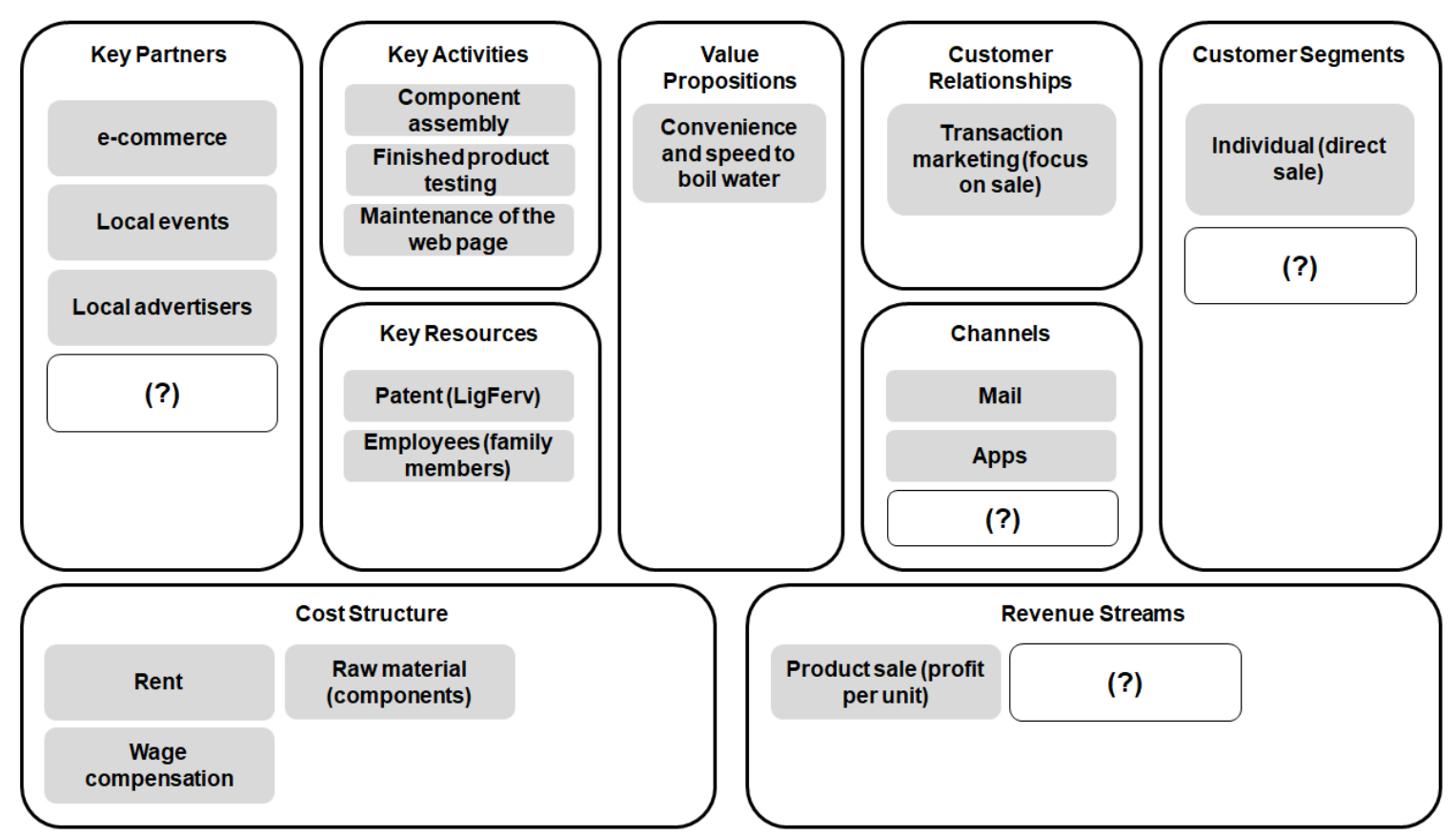

Figure 6. Initial proposal for Faciletec (2006-2018). 


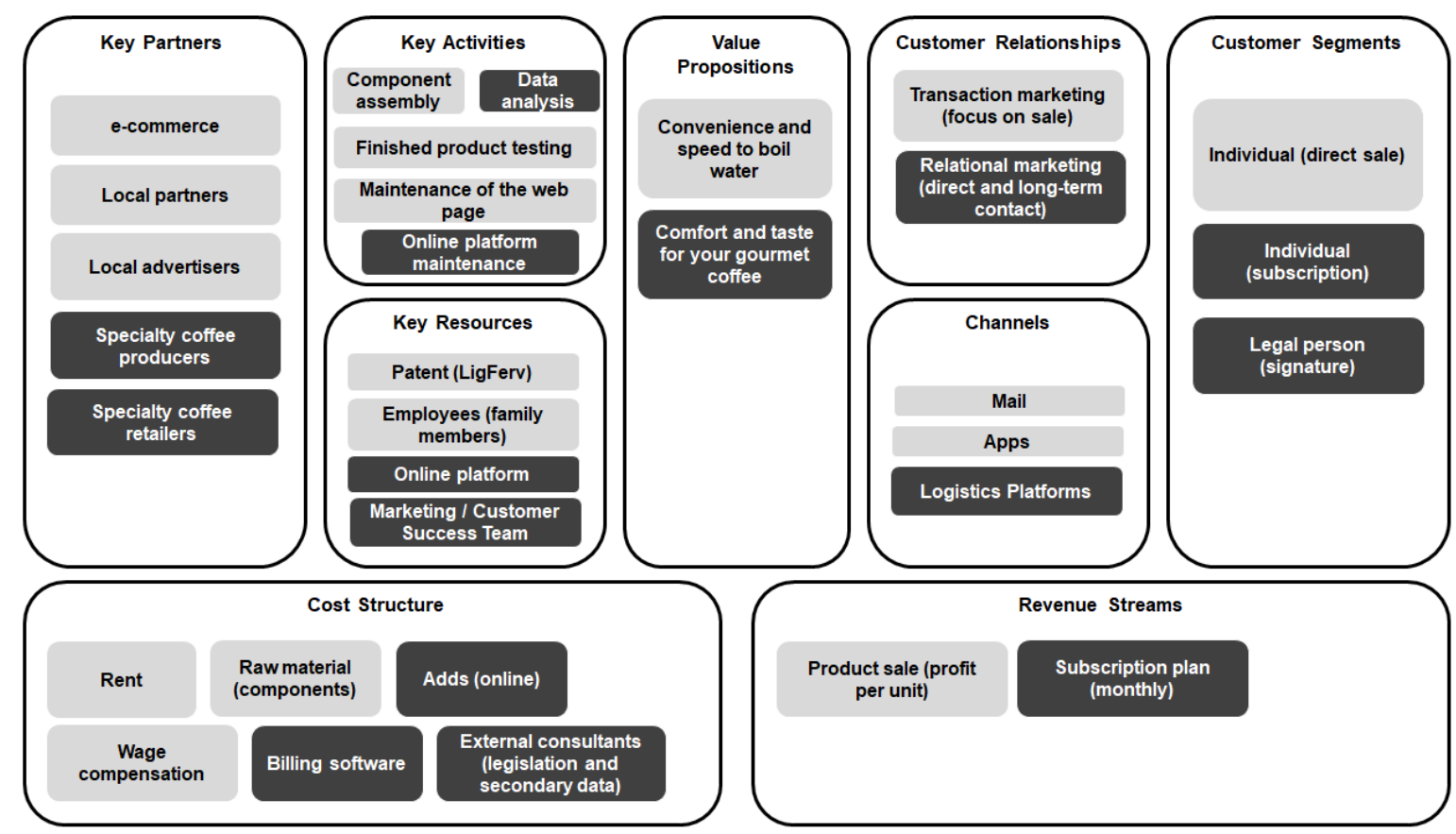

Figure 7. Proposed integrated framework for Faciletec (2018).

\section{REFERENCES}

Albuquerque, F. (2020, May). Compras com cartôes crescem 14,1\% no primeiro trimestre, diz Abecs. Agência Brasil. Retrieved from https://agenciabrasil.ebc.com.br/economia/ noticia/2020-05/compras-com-cartoes-crescem-141-noprimeiro-trimestre-diz-abecs\#: : :text=Levantamento $\% 20$ feito $\% 20$ pela $\% 20$ Associa $\%$ C $3 \%$ A $7 \%$ C 3\%A3o $\% 20$ Brasileira, R\%24\%20475\%2C7\%20bilh\%C3\%B5es

Andreini, D., \& Bettinelli, C. (2017). Business model innovation: From systematic literature review to future research directions. Cham, Switzerland: Springer.

Associação Brasileira de Comércio Eletrônico (2017, February). Clubes de assinatura aproximam clientes. Retrieved from https://abcommsc.com.br/2017/02/08/clubes-de-assinaturaaproximam-clientes/

Barbo, L. (2020, April). Clubes de assinatura podem ser alternativa para minimizar a crise. Jornal de Brasilia. Retrieved from https://jornaldebrasilia.com.br/gastronomia/lu-barbo/ clubes-de-assinatura-podem-ser-alternativa-para-minimizar$\underline{\text { a-crisel }}$

Bourry, E. C. M. S., \& Teixeira, A. C. C. (2019). Effectuation logic. Revista de Empreendedorismo e Inovação Sustentáveis, 4(1), 64-80. Retrieved from http://revista.isaebrasil.com.br/ index.php/EGS/article/view/30
Citi (2020). Signing up to the subscription economy: The race for recurring revenue in Asia Pacific. Retrieved from https://www.citibank.com/tts/insights/articles/article81.html

DaSilva, C. M., \& Trkman, P. (2014). Business model: What it is and what it is not. Long Range Planning, 47(6), 379-389. https://doi.org/10.1016/j.lrp.2013.08.004

Feger, J. E., Vieira, R. S., \& Chemin, M. (2016). Relação entre as características centrais empreendedoras e o processo de criaçáo de empresas: um estudo exploratório. Revista de Administração, Contabilidade e Economia, 15(3), 10351064. http://dx.doi.org/10.18593/race.v15i3.8875

Ferreira, K. F. O. (2020). Análise do processo empreendedor a partir das lógicas effectuation e causation: Um estudo de caso em duas empresas mineiras (Master Thesis). Pontifícia Universidade Católica de Minas Gerais, Belo Horizonte, MG, Brazil. Retrieved from http://www.biblioteca.pucminas.br/teses/ Administracao KarinaFernandaOliveiraFerreira 8559.pdf

Hisrich, R. D., Peters, M. P., \& Shepherd, D. A. (2014). Empreendedorismo (9. ed.). Porto Alegre: Amgh Editora.

Osterwalder, A., \& Pigneur, Y. (2003). An ontology for e-business models. In W. L. Currie (Ed.), Value creation from e-business models (p. 65-97). Oxford, UK: Butterworth-Heinemann. https://doi.org/10.1016/B978-0-7506-6140-9.X5000-0 
Osterwalder, A., \& Pigneur, Y. (2010). Business model generation: $A$ handbook for visionaries, game changers, and challengers. New Jersey: Wiley.

Sarasvathy, S. D. (2001). Causation and effectuation: Toward a theoretical shift from economic inevitability to entrepreneurial contingency. Academy of Management Review, 26(2), 243-263. https://doi.org/10.5465/amr.2001.4378020

Sarasvathy, S. D. (2003). Entrepreneurship as a science of the artificial. Journal of Economic Psychology, 24(2), 203-220. https://doi.org/10.1016/S0167-4870(02)00203-9

Sarasvathy, S. D., \& Dew, N. (2005). New market creation through transformation. Journal of Evolutionary Economics, 15, 533-565. https://doi.org/10.1007/s00191-005-0264-x
Sarasvathy, S. D., Forster, W., \& Ramesh, A. (2020). From Goldilocks to Gump: Entrepreneurial mechanisms for everyday entrepreneurs. REGEPE - Revista de Empreendedorismo e Gestão de Pequenas Empresas, 9(1), 189-220. http://dx.doi.org/10.14211/regepe.v9i1.1803

Simóes, K. (2019). Clubes de assinatura já faturam mais de R \$1 bi. Valor Econômico. Retrieved from https://valor.globo.com/ publicacoes/suplementos/noticia/2019/11/29/clubes-deassinatura-ja-faturam-mais-de-r-1-bi.ghtml

Teece, D. J. (2017). Business models and dynamic capabilities. Long Range Planning, 51(1), 40-49. https://doi.org/10.1016/j.lrp.2017.06.007

Zuora (2019). Subscription economy index. Retrieved from https:// www.zuora.com/resource/ subscription-economy-index/ 


\section{Authorship}

\section{João Paulo Moreira Silva}

Pontifícia Universidade Católica de Minas Gerais, Programa de Pós-graduação em Administração

Av. Itaú, no 525, Dom Cabral, 30535-012, Belo Horizonte, MG, Brazil.

E-mail address: joao.msilva@live.com

(D) https://orcid.org/0000-0002-9470-2905

\section{Liliane de Oliveira Guimarães*}

Pontifícia Universidade Católica de Minas Gerais, Programa de Pós-graduação em Administração

Av. Itaú, no 525, Dom Cabral, 30535-012, Belo Horizonte, MG, Brazil.

E-mail address: lilianeog@pucminas.br

(1) https://orcid.org/0000-0002-3346-2207

\section{José Márcio de Castro}

Pontifícia Universidade Católica de Minas Gerais, Programa de Pós-graduação em Administração

Av. Itaú, no 525, Dom Cabral, 30535-012, Belo Horizonte, MG, Brazil.

E-mail address: josemarcio@pucminas.br

(1) https://orcid.org/0000-0002-3170-9456

* Corresponding Author

\section{Funding}

The authors thank the Fundação de Amparo à Pesquisa do Estado de Minas Gerais (FAPEMIG) for the financial support to the research of this article.

\section{Conflict of Interests}

The authors have stated that there is no conflict of interest.

\section{Plagiarism Check}

The RAC maintains the practice of submitting all documents approved for publication to the plagiarism check, using specific tools, e.g.: iThenticate.

\section{Authors' Contributions}

$1^{\text {st }}$ author: conceptualization (equal); investigation (equal); methodology (equal); visualization (equal); writing-original draft (equal); writing-review $\&$ editing (equal).

$2^{\text {nd }}$ author: conceptualization (lead); investigation (equal); methodology (equal); project administration (equal); supervision (equal); visualization (equal); writing-review \& editing (equal).

$3^{\text {rd }}$ author: conceptualization (equal); investigation (equal); methodology (equal); project administration (equal); supervision (equal); writing-review $\&$ editing (equal).

\section{Copyrights}

RAC owns the copyright to this content.

\section{Peer Review Method}

This content was evaluated using the double-blind peer review process. The disclosure of the reviewers' information on the first page, as well as the Peer Review Report, is made only after concluding the evaluation process, and with the voluntary consent of the respective reviewers and authors.

\section{Data Availability}

All data and materials have been made publicly available through the Harvard Dataverse platform and can be accessed at:

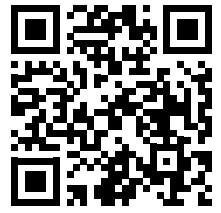

João Paulo Moreira Silva; Liliane de Oliveira Guimarães; José Márcio de Castro, 2021, "Replication Data for: "Facile/LigFerv: Hot water in three seconds, thirty years of entrepreneurial process"', Harvard Dataverse, V1. https://doi.org/10.7910/DVN/PHRAKH

RAC encourages data sharing but, in compliance with ethical principles, it does not demand the disclosure of any means of identifying research subjects, preserving the privacy of research subjects. The practice of open data is to enable the reproducibility of results, and to ensure the unrestricted transparency of the results of the published research, without requiring the identity of research subjects. 


\section{APPENDIX A.}

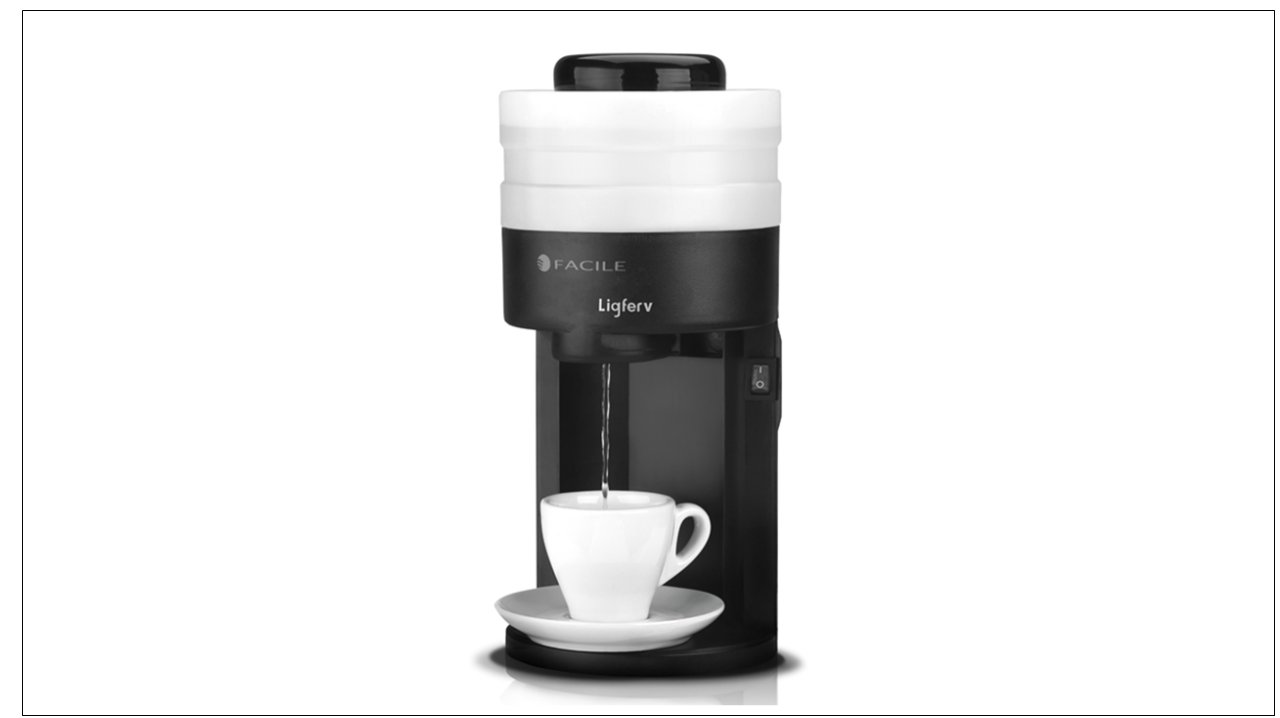

Figure A1. Current model — LigFerv.

Source: Photo provided by the interviewed entrepreneur.

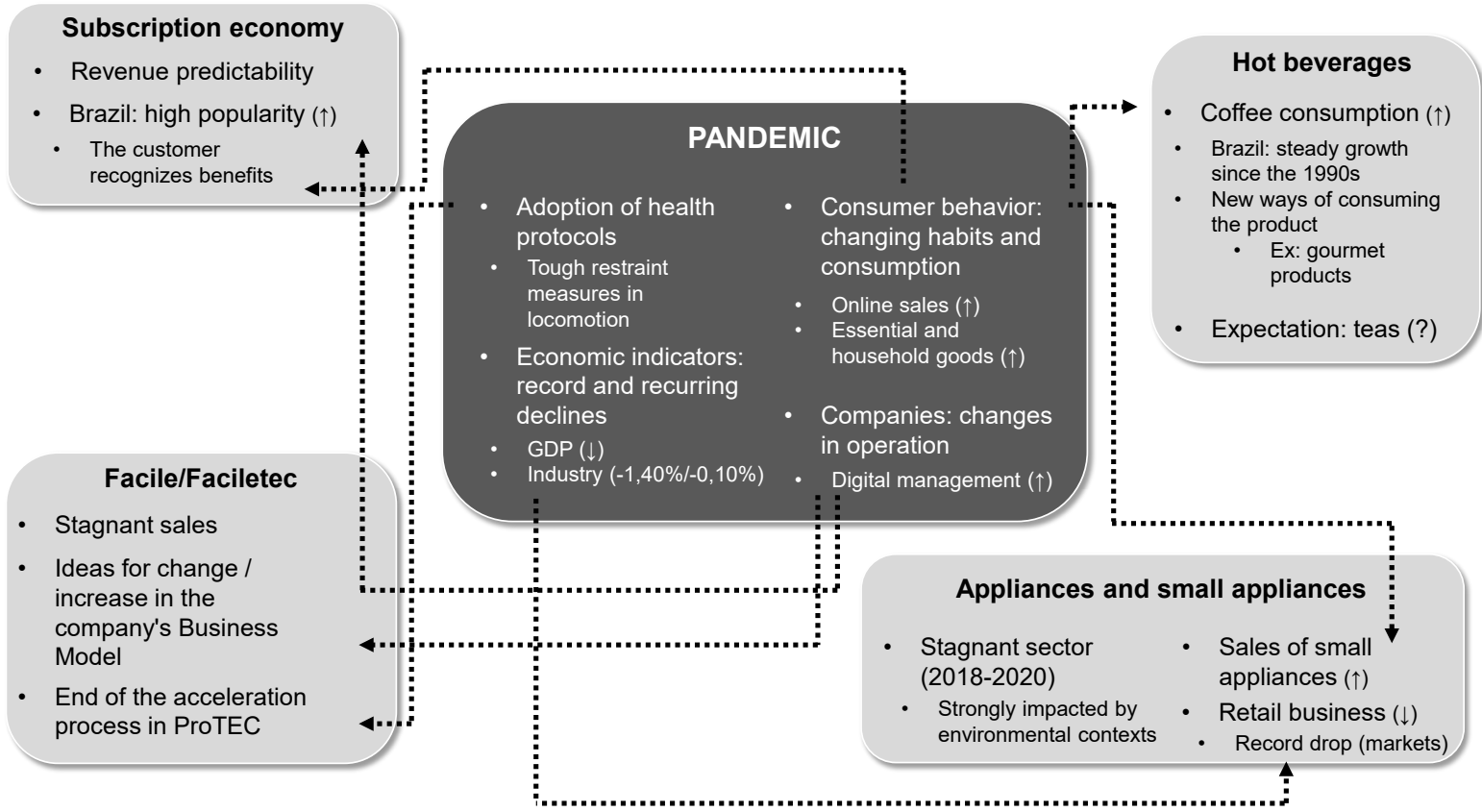

Figure A2. General scheme proposed for plenary discussion.

Source: Elaborated by the authors. 